\title{
МОЛЕКУЛЯРНАЯ ГЕОХИМИЯ РАССЕЯННОГО ОРГАНИЧЕСКОГО ВЕЩЕСТВА ПОЗДНЕКАЙНОЗОЙСКИХ ОТЛОЖЕНИЙ ЛАПТЕВОМОРСКОЙ КОНТИНЕНТАЛЬНОЙ ОКРАИНЫ И ПРИЛЕГАЮЩЕЙ ЧАСТИ СЛО
}

Петрова В. И., Батова Г. И., Литвиненко И. В., Куршева А. В., Моргунова И. П.

\begin{abstract}
Аннотация
На основе геоморфологической, литологической и органо-геохимической характеристик исследовались основные факторы, контролирующие формирование в позднем кайнозое рыхлых осадочных отложений Сибирского сегмента хребта Ломоносова (осевая часть и западный склон) и континентального склона моря Лаптевых. Анализ группового и молекулярного состава рассеянного органического вещества (РОВ) осадков, отобранных в ходе научно-исследовательских рейсов НЭС “Академик Федоров» $(2005,2007 г г$.$) и атомного ледокола «Россия (2007г.) показал,$ что осадконакопление на лаптевоморском континентальном склоне и в котловине Амундсена определяется преимущественно поступлением терригенного осадочного материала, обогащённого продуктами абразии литифицированных пород. Индивидуальные особенности параметров, характеризующих РОВ позднекайнозойских отложений хребта Ломоносова, отражают многообразие источников осадочного материала и условий его депонирования. Наряду с терригенным стоком и ледовым разносом в процессе осадконакопления определённую роль играют процессы субаквального размыва эдафогенного материала и доголоценовых осадочных образований.
\end{abstract}

\section{Ключевые слова:}

донные отложения; геохимия; органическое вещество; углеводородные молекулярные маркеры; СЛО 


\title{
МОЛЕКУЛЯРНАЯ ГЕОХИМИЯ РАССЕЯННОГО ОРГАНИЧЕСКОГО ВЕЩЕСТВА ПОЗДНЕКАЙНОЗОЙСКИХ ОТЛОЖЕНИЙ КОНТИНЕНТАЛЬНОЙ ОКРАИНЫ И ПРИЛЕГАЮЩЕЙ ЧАСТИ СЕВЕРНОГО ЛЕДОВИТОГО ОКЕАНА.
}

\author{
В.И. Петрова, Г.И. Батова, А.В. Куршева, И.В. Литвиненко, И.П. Моргунова
}

ВНИИОкеангеология, 190121, С-Петербург, Английский пр.,1, Россия

На основе геоморфологической, литологической и органо-геохимической характеристик исследовались основные факторы, контролирующие формирование в позднем кайнозое рыхлых осадочных отложений Сибирского сегмента хребта Ломоносова (осевая часть и западный склон) и континентального склона моря Лаптевых. Анализ группового и молекулярного состава рассеянного органического вещества (РОВ) осадков, отобранных в ходе научно-исследовательских рейсов НЭС “Академик Федоров» (2005, 2007г2.) и атомного ледокола «Россия (20072.) показал, что осадконакопление на континентальном склоне моря Лаптевых и в котловине Амундсена определяется преимущественно поступлением терригенного осадочного материала, обогащённого продуктами абразии литифицированных пород. Индивидуальные особенности параметров, характеризующих РОВ позднекайнозойских отложений хребта Ломоносова, отражают многообразие источников осадочного материала и условий его депонирования. Наряду с терригенным стоком и ледовым разносом в процессе осадконакопления определённую роль играют процессы субаквального размыва эдафогенного материала и доголоценовых осадочных образований.

Одной из характерных черт полярного литогенеза является тесная связь литологического, минералогического и химического состава донных отложений с областями сноса осадочного материала [Данилов, 1978]. Чрезвычайно интенсивный речной сток, береговая и донная абразия, ледовый разнос, активная гидродинамика создают сложную мозаичную картину, интерпретация которой предполагает детальное рассмотрение всей совокупности факторов [Система моря Лаптевых..., 2009]. И, если осадконакопление на внутреннем восточно-арктическом шельфе в голоцен-четвертичное время происходило, в основном, под влиянием речного стока и береговой абразии [Tessi et al., 2016], то донные отложения внешнего шельфа и, в особенности, континентального склона и его абиссального продолжения представляют собой стратифицированную последовательность потоков осадочного вещества, позволяющих оценить вклад широкого спектра источников [The organic carbon..., 2004; Левитан и др., 2007].

До недавнего времени считалось [Jakobsson et al., 2001; Polyak et al., 2004], что состав позднекайнозойского рыхлого осадочного чехла восточно-арктической континентальной окраины определяют два основных источника осадочного материала:

- $\quad$ в периоды ледниковья - гидросферный перенос терригенного осадочного вещества; 
- $\quad$ в периоды дегляциации - гидросферный перенос терригенного материала и ледовый/айсберговый разнос коренных пород, слагающих питающие провинции.

Вместе с тем, относительная значимость иных источников в процессе осадконакопления до сих пор является дискуссионной. Так, в работе В.Я. Кабанькова и соавторов [Кабаньков и др., 2004] было показано, что донные осадки такой расчлененной области, как дно центральной части Северного Ледовитого океана (СЛО), в значительной мере формируются за счет склоновых процессов и образования элювиальноделювиальных осадков с участием плотных древних пород. При этом имеет место смешение с осадками других типов, в частности с осадками, связанными с деятельностью придонных течений.

Исследование 50 сантиметровой колонки глубоководных илов [Гусев и др., 2008], отобранной в северной части котловины Амундсена вблизи северо-западного склона хребта Ломоносова показало, что наличие небольшого количества переотложенных неритических диатомей плейстоценового и палеогенового возраста свидетельствует об участии в их образовании вещества, снесенного с северной окраины России. Вместе с тем, минеральный и химический составы, а также присутствие в осадках переотложенных палиноморф палеозойского и мезозойского возраста, сходных с таковыми из углистых алевролитов, встреченных на склоне хр. Ломоносова, позволили предположить формирование илов в результате осаждения продуктов подводного размыва склонов этого хребта. Данные выводы согласуются с результатами, приведенными в работе [Grantz et al., 2001], где описывается образец брекчии, поднятый на евразийском склоне хребта Ломоносова, состоящий из обломков неморских углистых алевролитов, имеющих, судя по палиноморфам, мезозойский возраст. Авторы пришли к выводу, что подобные породы могут слагать мезозойский разрез хр. Ломоносова, залегающий ниже нижнепалеогенового несогласия.

Таким образом, и особенно, в свете новых данных о выходах на склонах глубоководных поднятий (Поднятие Менделеева) коренных скальных пород значительной мощности (эскарпов) [Гусев и др., 2014], а также благодаря обнаружению на западном склоне хребта Ломоносова выхода миоценовых, а возможно и более ранних отложений [Stein et al., 2016], можно предположить участие процессов дезинтеграции и переотложения in situ в формировании позднекайнозойских осадков амеразийской континентальной окраины.

Основной идеей данного исследования явилось изучение состава углеводородных молекулярных маркеров донных отложений Лаптевоморской континентальной окраины как индикаторов происхождения осадочного материла. Как неотъемлемая часть суммарного седиментационного потока, рассеянное органическое вещество проходит весь путь от зоны иммобилизации до бассейна конечной седиментации, кодируя в своей молекулярной структуре геологическую судьбу осадочного материала [Петрова и др., 2010]

\section{МАТЕРИАЛЫ И МЕТОДЫ}

Материалом исследования послужили осадочные колонки, отобранные гидростатическими грунтовыми трубками в ходе экспедиционных работ НЭС «Академик 
Фёдоров» 2005, 2007 гг. и АЛ «Россия» 2007 г. (рис.1). Колонки отбирали на внешнем шельфе моря Лаптевых (АФ-07-26, АФ-05-29), континентальном склоне (АФ-05-31), его подножии (АФ-05-33) и абиссальном продолжении в котловине Амундсена (АФ-05-34). А также в зоне сочленения континентального склона моря Лаптевых с Сибирским сегментом [Рекант и др., 2018] хребта Ломоносова и в осевой его части до 83ㅁ.ш. При этом, часть станций проботбора располагалась на вершинных плато (АЛР-07-17; АЛР-07-22), часть была приурочена к крутым склонам хребта (АЛР-07-18; АЛР-07-28), где, по сейсмическим данным, предполагались выходы коренных пород [Рекант и др., 2105].

Образцы для камеральных исследований помещали в стерильную тару и сохраняли при $-18^{\circ} \mathrm{C}$. Определение содержания органического (Сорг) и карбонатного (Скарб) углерода проводили методом Кнопа (химическое сжигание). Аналитическая процедура изучения органической составляющей осадков (РОВ) включала: экстракцию битумоидов, определение их группового состава, хроматографическое фракционирование с выделением суммы метано-нафтеновой и ароматической фракций УВ, ГХ-МС анализ налканов, циклических и полиароматических (ПАУ) углеводородов.

ГХ-МС анализ углеводородных фракций проводили на комплексе Hewlett Packard 6850/5973 с квадрупольным масс-детектором и программным комплексом обработки аналитической информации. Анализ насыщенных УВ проводили на капиллярной колонке HP DB 30 м х 0.25 мм с неподвижной фазой 5\%фенил/95\%метилсиликон; газ-носитель гелий, скорость потока 1.2 мл/мин; температура инжектора $320^{\circ} \mathrm{C}$; температурный режим анализа: от $50^{\circ} \mathrm{C}$ до $320^{\circ} \mathrm{C}$ по $3^{\circ} \mathrm{C} /$ мин и 7 мин при $320^{\circ} \mathrm{C}$; детектирование - по полному ионному току (SCAN от 50 до $500 \mathrm{~m} / \mathrm{z}, 70 \mathrm{eV}$ ). Алкановые УВ идентифицировали по селективному иону (SIM) $71 \mathrm{~m} / \mathrm{z}$, циклановые УВ - по 191 и $217 \mathrm{~m} / \mathrm{z}$. Анализ ПАУ проводили на той же колонке; газ-носитель - гелий, скорость потока 1.2 мл/мин; температура инжектора $290^{\circ} \mathrm{C}$; температурный режим анализа: от $60^{\circ} \mathrm{C}$ до $200^{\circ} \mathrm{C}$ по $20^{\circ} \mathrm{C} /$ мин, до $300^{\circ} \mathrm{C}$ по $10^{\circ} \mathrm{C}$ и 5 мин при $300^{\circ} \mathrm{C}$; детектирование - по полному ионному току (SCAN от 50 до $500 \mathrm{~m} / \mathrm{z}, 70 \mathrm{eV}$ ). Голоядерные ПАУ идентифицировали по селективным ионам (SIM) 128, 152, 154, 178, 184, 202, 228, 252, 276, 278 m/z; алкилированные - по селективным ионам (SIM) - 142, 156, 192, 206, 220, 216, 234, 242 m/z.

\section{ХАРАКТЕРИСТИКА РАЙОНА ИССЛЕДОВАНИЙ}

Шельф моря Лаптевых в морфоструктурном плане - пластовая равнина, осложненная реликтовыми речными долинами, при этом мощность голоценовых осадков в областях с преобладанием размыва колеблется от 0 до 20-25 см, а зонах, благоприятных для осадконакопления, может достигать нескольких метров [Романкевич, Ветров,. 2001]. Кромка внешнего шельфа и наклонные аккумулятивные равнины материкового склона расчленены подводными каньонами, к которым выходят низовья реликтовых подводных долин шельфа. Материковое подножие хорошо выражено и плавно переходит в абиссальную равнину котловины Амундсена [Зинченко 2018]. Хребет Ломоносова представляет вытянутое в меридиональном направлении горное поднятие, вдоль гребневой части которого локализованы осложняющие формы рельефа: плато, седловины, террасы, отроги. Выделенный по морфологическим и геолого-геофизическим признакам Сибирский сегмент занимает южную часть хребта и характеризуется резкой 
асимметричностью поперечных сечений при крутом западном склоне и пологом восточном [Рекант, Гусев, Виноградов, 2009; Рекант и др, 2018].

\section{ОБСУЖДЕНИЕ РЕЗУЛЬТАТОВ}

\section{Общая геохимическая характеристика РОВ}

Колонки, отобранные на внешнем шельфе (АФ-07-26) и его кромке (АФ-05-29), где основной поток осадочного материала контролируется мощным выносом речного стока и Трансполярным дрейфом [Kassens et al., 1999; The organic carbon..., 2004], представлены преимущественно монотонной толщей алевропелитов (от серых до почти черных), являющихся типичными шельфовыми отложениями, сформированными в восстановительных условиях (рис.2). Бескарбонатные (Скарб<0,05\%), обогащенные Сорг (>1\%), гуминовыми кислотами (до 0,66\%) и битумоидными компонентами (до 0,07\%) (табл. 1) разности, отражают значительный масштаб поступления в этот район гумусового осадочного материала, поставляемого речным стоком.

В осадочном разрезе зоны континентального склона (АФ-05-31) интенсивное влияние терригенного сноса в целом сохраняется (Скарб $<0,01$, Сорг $=0,50-0,80 \%$, $\Gamma K=0,03-0,19 \%)$, заметно нивелируясь в осадках его подножия (АФ-05-33) (Скарб <0,01, Сорг $=0,3-0,6 \%, \Gamma K<0,01 \%)$. В северной части котловины Амундсена (АФ-05-34) в осадочном разрезе чередуются бескарбонатные и слабокарбонатные (Скарб до 0,20\%) прослои с характерным для глубоководной части СЛО содержанием POB [The organic carbon..., 2004] постдиагенетического уровня трансформации (Сорг $<0,40 \%$, ГК=0\%, ООВ до 98\%), Полученные результаты согласуются с данными, приведенными в работе [Belicka et al., 2002], согласно которым в поверхностных донных осадках, отобранных на Северном полюсе, фиксируется РОВ смешанного гидробионтно-терригенного генезиса $(\mathrm{C} / \mathrm{N}<10)$.

Литологический состав осадков, отобранных на гребневой и склоновой частях хребта Ломоносова, в отличие от отложений континентального склона и абиссали, более разнообразен. Несмотря на то, что в большинстве своем донные отложения представлены алевропелитовой фракцией, в разрезе наблюдается значительная изменчивость литологии, текстуры и структуры, цвета и плотности осадка.

Осадки, отобранные на юго-западном склоне хребта Ломоносова, обращенного в сторону котловины Амундсена (ст. АЛР-07-28) во всем стратиграфическом разрезе (10 м) представлены преимущественно бескарбонатными пелитовыми и алевропелитовыми разностями. Среднее содержание органического углерода (Сорг) в осадках верхней части разреза $(<800 \mathrm{~cm})$ не превышает $0,22 \%$, что характерно для глубоководных осадков Арктического бассейна. Типичным также является низкое содержание битумоидов и отсутствие гуминовых кислот.

Однако, в нижней части разреза (>800см), в сероцветных пелитах (ст.АЛР-0728сц), на фоне незначительного увеличения грубозернитости (>0,63мм до 10\%) наблюдается резкое, более чем в 2 раза, увеличение содержания РОВ (Сорг $>0,5 \%)$ и его растворимых компонентов (Ахл =0,014\%). При этом существенно снижается уровень преобразованности РОВ, на что указывает появление в его составе гуминовых кислот $(\Gamma K=0,16 \%)$ и снижение содержания керогена. (ООВ $<80 \%)$. Данное изменение геохимических параметров может быть обусловлено интенсивным поступлением в этот 
период осадочного вещества, обогащенного терригенным (гумусовым) органическим материалом.

Сходная картина наблюдается в осадочном разрезе станции АЛР-07-18 (осадочная колонка 9 м), расположенной на крутом западном склоне в северной части Сибирского сегмента хребта. Здесь на глубине более 300см (ст. АЛР-07-18сц) также отмечается значительное увеличение содержания $\mathrm{POB}$ (Сорг=0,54\%) и его растворимых компонентов (Ахл, ГК), наиболее ярко выраженное в интервале 500-700см (табл. 1). Однако, в отличие от отложений южного склона данный осадочный разрез характеризуется спорадическим повышенным содержания грубозернистой фракции, в ряде интервалов достигающего 45\%. При этом, если в верхней части разреза не наблюдается корреляции грубозернистости с содержанием Сорг, то в нижней части такая связь заметна.

Осадочные отложения, приуроченные к гребневой части хребта Ломоносова (ст. АЛР-07-17, АЛР-07-22) по геохимическим параметрам РОВ отличаются от склоновых разрезов, рассмотренных выше. Отложения характеризуются переслаиванием коричневых и оливковых пелитов и алевропелитов, при этом в верхних трех метрах разреза отмечается присутствие характерной «пилообразной» кривой распределения песчаной фракции [Jakobsson et al., 2001]. При этом осадочные разрезы не включают прослоев сероцветных пелитов и, соответственно, характеризуются низким содержанием Сорг ( $<0,3 \%)$. Высокое содержание керогена (ООВ > 98\%) и отсутствие гуминовых кислот свидетельствуют о значительном уровне трансформации РОВ. Осадочный материал, содержащий РОВ постдиагенетической стадии зрелости может быть как привнесенным (терригенный сток, ледовый разнос), так и переотложенным.

\section{Характеристика молекулярного состава РОВ}

Реликтовые биомаркеры различного строения (алканы, стераны, гопаны, ароматические цикланы), несут генетическую информацию о природе исходного органического вещества, что позволяет оценить вклад различных источников в формирование осадочных отложений, охарактеризовать условиях их накопления и уровень преобразования, а также дают информацию для лито-фациальных реконструкций [Eglinton,Murphy 1969; Brassel et. al., 1987; Peters, Walters, Moldowan, 2005; Innes et al., 1998; Nytoft et al., 2001; Bastow et al.,2001; Hautevelle et al., 2006; Greenwood et al, 2006].

В изученных осадках распределение алифатических углеводородов (н-алканов и изопреноидов) свидетельствует о доминирующем влиянии терригенного стока на формирование состава РОВ. Достигая максимальных значений в осадках внешнего шельфа, содержание высокомолекулярных углеводородов (TAR=14,9) [Peters, Walters, Moldowan, 2005] с высоким индексом нечетности (CPI>2; $\mathrm{OEP}_{27-31}>4$ ) маркирует поток гумусового осадочного материала, поступающего с шельфа моря Лаптевых. При этом, даже в осадочных отложениях наиболее глубоководной части котловины Амундсена эти показатели остаются весьма значительным (TAR=2,0; CPI $>2$; $\mathrm{OEP}_{27-31}>4$ ), что отмечалось и в работе [Yunker et al., 2011]. Пониженные значения индекса нечетности низкомолекулярных н-алканов $\left(\mathrm{OEP}_{17-19} \leq 1\right)$ могут отражать как избирательную деградацию сапропелевого ОВ в седименогенезе, так и участие в формировании состава 
осадков глубоко преобразованного РОВ осадочных пород. На это указывает и заметное содержание литифицированных (термально зрелых) (Lithic n-Alk/g Corg) [Yamamoto, Polyak, 2009] соединений в составе н-алканов, закономерно возрастающее в направлении пелагиали (табл. 3).

Широкий разброс значений изопреноидных коэффициентов на диаграмме КеннонаKeccoy [Connon, Cassou,1980], характеризующих осадки зоны перехода от шельфа в глубоководную часть котловины Амундсена (рис. 3), свидетельствуют о значительном многообразии источников осадочного материала, поставщиками которого могу быть гидросферный перенос, ледовый разнос и денудация выходов древних отложений. Так, низкое значение изопреноидных коэффициентов осадков ст. АФ-07-26 может быть обусловлено поступлением в осадки продуктов размыва и переотложения термально зрелых пород [Shanmugam, 1985], слагающих о. Бельковский, вблизи которого находилось место пробоотбора. Однако, по мнению авторов работы [van Koeverden et al., 2011], аномально низкие значения изопреноидных коэффициентов связаны со спецификой фациальных обстановок осадконакопления, а не с термальной зрелостью. Действительно, данные отложения характеризуются наименьшим содержанием термально зрелых (литифицированных) соединений в составе н-алканов (табл.3). В целом же, значительные вариации фациальных условий формирования РОВ - от лагунно-озёрных до морских, указывают на многообразие источников осадочного материала, обеспеченного широким спектром областей сноса СЛО [Система моря Лаптевых, 2009, Рекант и др., 2018]. Осадочные отложения, приуроченные к склоновой и гребневой частям хребта Ломоносова, характеризуются компактными совокупностями изопреноидных индексов, что обусловлено, очевидно, определённой детерминированностью потоков осадочного материала, содержащего РОВ, сформированного преимущественно в мелководно-морских фациальных условиях. При этом РОВ осадков гребневой зоны (АЛР-07-22, АЛР-07-17) характеризуется большей термальной зрелостью, чем РОВ склоновых отложений (рис. 3). Приведённые в работе [Рекант и др. 2018] результаты минералогического анализа показали, что в составе обломочного материала, выделенного из осадков ст. АЛР-07-17, присутствуют породы, сходные с породами складчато-метаморфического фундамента о-ва Генриетта, что может обуславливать высокий уровень термальной зрелости РОВ осадков данного осадочного разреза. По-видимому, осадконакопление на ст. АЛР-07-22, находящейся в близкой морфоструктурной позиции, проходило в сходных условиях.

Наибольшее содержание гумусового РОВ в осадках склоновых разрезов наблюдается в прослоях сероцветных отложений (TAR>5) (табл. 3). Согласно общим геохимическим параметрам (табл. 1, 2), данные отложения находятся на более низкой стадии трансформации, чем вышележащие. Однако, содержание литифицированных компонентов (Lithic n-Alk mkg/g Corg) в них отличается незначительно, а индексы нечётности (ОЕР) даже несколько ниже, что может быть обусловлено поступлением наряду с осадочным материалом, содержащим слабо преобразованное РОВ (наличие гуминовых кислот), продуктов денудации более зрелых пород.

Фациально-генетическая характеристика РОВ, основанная на анализе состава стеранов, соотношения в гомологическом ряду которых $\left(\mathrm{C}_{27} / \mathrm{C}_{28} / \mathrm{C}_{29}\right)$ характеризуют вклад сапропелевого и гумусового ОВ, не противоречит данным по распределению алифатических биомаркеров. Приведённая на рис.4 тригонограмма свидетельствует об 6 
определённых отличиях фациальных условий формирования РОВ изученных отложений. Так, осадки внешнего шельфа (АФ-07-26) и сероцветные отложения юго-западного склона хребта Ломоносова (ст. АЛР-07-28сц) обогащены гумусовым ОВ и тяготеют к лагунноконтинентальным фациям. Мористые фациальные условия характерны для отложений верхней части осадочного разреза западного склона хребта (ст. АЛР-07-18). Остальные изученные разрезы содержат РОВ, сформированное преимущественно в прибрежноморских условиях. Особо следует отметить, что фациальные условия формирования сероцветных отложений ст. АЛР-07-18 заметно отличаются от таковых для сероцветов юго-западного склона хребта Ломоносова (ст. АЛР-07-28сц), что позволяет предположить различия в источниках осадочного материала.

Если стерановые коэффициенты, характеризующие генотип РОВ изученных осадочных отложений как достаточно однородный, преимущественно сапропелевогумусовый, а фациальные обстановки формирования как прибрежные и мелководноморские, то показатели термальной зрелости варьируют в весьма широких пределах. Диаграмма соотношения гомогопанового и трисноргопанового индексов зрелости (рис. 5) наглядно иллюстрирует данный вывод. В зоне перехода от внешнего шельфа в пелагиаль котловины Амундсена наблюдается закономерное увеличение в осадках термальной зрелости РОВ. При этом, осадки внешнего шельфа заметно отличаются от осадков континентального склона и пелагиали, что может быть обусловлено различием в источниках осадочного материала. В первом случае доминирует, очевидно, терригенный сток, в пелагической области - ледовый разнос и, возможно, денудационные процессы [Кабаньков и др. 2004].

Осадки гребневой части хребта Ломоносова и верхней части разрезов склоновых осадочных колонок, так же как и осадки котловины Амундсена, содержат РОВ постдиагенетического уровня трансформации. А наименьшими значениями гомогопановых и трисноргопановых индексов термальной зрелости характеризуются сероцветные отложения склоновых осадочных разрезов.

Присутствие сероцветных прослоев, обогащенных терригенным материалом, в осадочных разрезах голоцен-четвертичных отложений амеразийской континентальной окраины обычно обосновывают подлёдной седиментацией в периоды перехода от максимума оледенения к дегляциации (6/5 MIS; 4/3 MIS) [Jakobsson et al., 2001]. При этом происхождение осадочного материала, формирующего эти прослои, связывают с различными источниками.

Так, в работе [Stein, R. et al, 2001] возможными источниками терригенного органического вещества, отложившегося в низах разреза осадочной колонки, отобранной на хребте Ломоносова (PS 2757-8), названы мезозойские породы архипелага Земля Франца-Иосифа и угольные отложения в районе между севером полуострова Таймыр и районом реки Лена. Авторы предположили, что в период дегляциации породы, богатые органическим углеродом, были разрушены, и материал был транспортирован к прилегающей континентальной окраине под влиянием Трансарктического дрейфа. Низкий уровень термальной зрелости изученных сероцветных отложений не позволяет связать их с этими источниками.

[Yamamoto et al., 2008] пришли к выводу, что в отложениях позднего плейстоцена (колонка M0004С; АСЕХ, хр. Ломоносова) темно-серый слой, обогащённый РОВ, был 7 
отложен во время морской изотопной стадии MIS 6. Анализ состава углеводородных маркеров позволил предположить ледяную эрозию континентальных почв с последующей транспортировкой до центральной Арктики дрейфующим льдом.

С целью выявить приуроченность сероцветных отложений колонки АЛР-07-28 к определённому стратиграфическому интервалу и определить механизм их формирования было проведено сопоставление данного осадочного разреза с разрезом отобранной в непосредственной близости колонки АЛР-07-26 [Талденкова и др., 2009]. Детальный литолого-микрофаунистический анализ позволил авторам провести стратиграфическое расчленение осадочного разреза. Так, интервал 0-30 см был отнесён к голоцену и предшествующей эпохе дегляциации, граница 3 и 4 изотопно-кислородных стадий приурочена к интервалу 150-220 см; граница 4/5 изотопных стадий - около 270 см; граница 5/6 изотопных стадий - 360-390 см; и, наконец, к началу изотопной стадии 7 (?) отнесён интервал 580-650 см. Следует отметить, однако, что согласно полевому описанию данной колонки сероцветные отложения в ней присутствуют в интервале 650-700 см, то есть не соответствуют границе 5/6 изотопных стадий.

Близкое расположение колонок (рис. 6) и относительное сходство литологического состава (распределение грубозернистой фракции) позволяет провести сравнение осадочных разрезов и определить стратиграфическую позицию сероцветных отложений в колонке АЛР-07-28 как не соответствующую границе 5/6 МИС, а по-видимому более древнюю. Вместе с тем, геохимические параметры, характеризующие РОВ данных отложений свидетельствуют о поступлении в этот период осадочного материала, обогащенного слабо преобразованным гумусовым OB, на что указывает увеличение содержания высокомолекулярных н-алканов (TAR $>4$ ) и снижение циклановых коэффициентов термальной зрелости. Наряду с этим в составе цикланов возрастает доля гопанов и стеренов по отношению к стеранам, что также отражает незначительный уровень трансформации РОВ. Данная специфика РОВ находит подтверждение и в составе аренов, доминирующим компонентом в котором является перилен, характерный маркер терригенного ОВ, преобразование которого проходило в восстановительных условиях [Venkatesan et al., 1987; Suzuki et al., 2010].

Особо следует отметить высокие значения соотношения кадален/ретен. Учитывая, что кадален, биогенными предшественниками которого являются ароматические терпены, менее устойчив к транспортировке, чем ретен, продукт трансформации абиетанов [Остроухов и др., 2013], можно предположить относительную близость источника сноса. На это указывает вся совокупность биомаркерных показателей, поскольку лабильные компоненты органического вещества не сохраняются при переносе на дальние расстояния.

Таким образом, основным источником сероцветных отложений в осадочном разрезе колонки юго-западного склона хребта Ломоносова является, очевидно, терригенный осадочный материал, поставляемый в период регрессии моря, когда реки подходили вплотную к бровке шельфа.

Однако, сероцветные отложения, как было сказано выше, присутствуют в осадочных разрезах позднекайнозойских отложений хребта Ломоносова значительно севернее зоны его сочленения с континентальным склоном моря Лаптевых [Yamamoto et al., 2008]. 
Возникает вопрос, является ли формирование этих отложений результатом аналогичного процесса?

Сравнительные микрофаунистические исследования [Басов и Куприянова, 2010] осадочных колонок, отобранных на вершинном плато в северной части Сибирского сегмента хребта Ломоносова (АЛР-07-17) и на крутом западном склоне этого плато (АЛР07-18) (рис. 7), показали, что вскрытые в интервале от поверхности до глубины около 200240 см осадки в обеих колонках формировались в сходных условиях. По мнению авторов, это был застойный аноксидный бассейн с крайне неблагоприятной для обитания микрофауны обстановкой и с интенсивным периодическим привносом обломочного материала с шельфа, либо со склонов хребта.

Серые плотные глины, вскрытые в колонке АЛР-07-18 ниже 3 м, не имеют аналогов в колонке АЛР-07-17 и, по-видимому, отделены от вышележащих отложений перерывом. Нарушение седиментационной последовательности было зафиксировано так же в осадочной колонке, отобранной на ступенчатой части эскарпа западного склона хребта Ломоносова (PS87/106) [Stein et al., 2016]. Это несогласие характеризовалось заметным изменением цвета осадка, резким увеличение объемной плотности, значительным снижением магнитной восприимчивости и изменением в составе биомаркеров, маркирующим наличие в осадочном материале слабо преобразованного терригенного POB. Предварительные результаты микрофаунистического анализа позволили предположить позднемиоценовый возраст для нижней части осадочного разреза. Данное предположение согласуется с результатами интерпретации сейсмических профилей, приведённых в работе [Рекант, Гусев, 2012], согласно которым разрез осадочного чехла прилаптевоморской части хр. Ломоносова осложнён многочисленными несогласиями, в том числе олигоцен-миоценового возраста.

Сравнительный анализ литолого-геохимических параметров осадочных отложений данных колонок (рис. 7) свидетельствует об определённых чертах сходства условий осадконакопления верхних частей $(<3 \mathrm{M})$ осадочных разрезов. Так, в них наблюдается характерное пилообразное распределение грубозернистой фракции (> 0,063 мм) и, типичное для синокеанических осадков, низкое содержание Сорг $(<0,2 \%)$ [Романкевич, 1977]. Следует отметить, однако, что относительное содержание грубозернистой фракции в осадках колонки АЛР-07-18 заметно выше. Наряду с этим, наблюдаются и определённые отличия в составе молекулярных маркеров. В частности, в колонке, отобранной на вершинном плато, в составе терпанов заметно преобладают трицикланы, а в склоновой колонке значительно выше значение стеранового коэффициента термальной зрелости POB. Данная специфика может свидетельствовать о преимущественном влиянии дальнего переноса осадочного материала на осадконакопление в вершинной части хребта, поскольку трицикланы более устойчивы к биодеградации, чем гопаны [Peters, Moldowan, 2004]. Высокая термальная зрелость стеранов (K2) может быть обусловлена поступлением POB древних пород в процессе переотложения на крутых склонах. Так в работе [Рекант и др., 2013] на основе сравнительного анализа минералогических ассоциаций донных отложений прилаптевоморского сегмента хр. Ломоносова было показано, что для осадочных разрезов, расположенных вблизи крутых эскарпов, влияние ледового и айсбергового разноса на формирование минеральных ассоциаций не является 
определяющим. В них присутствует значительный объем продуктов размыва местных коренных источников.

Более того, петрографические и минералогические исследования обломочного материала из осадочной колонки АЛР-07-18 и его возрастная привязка по метаморфическим цирконам показали, что изученные терригенные породы имеют местное происхождение и характеризуют обнажения коренных пород in situ.

Однако, наибольшим своеобразием отличаются сероцветные отложения нижней части осадочного разреза колонки. В них заметно возрастает содержание РОВ (Сорг до 0,6\%), алифатические углеводороды представлены преимущественно нечётными высокомолекулярными соединениями (TAR=4,5; $\mathrm{OEP}_{27-31}=3$ ), что отражает доминирование гумусового материала диагенетического уровня трансформации.

Состав и распределение цикланов и аренов еще более определенно свидетельствуют об изменении природы РОВ в стратиграфическом разрезе донных отложений. Так, в верхней части разреза цикланы представлены почти исключительно геогопанами и геостеранами $(\mathrm{C} 30 \beta \alpha /(\alpha \beta+\beta \alpha)=0,1$; Sterene/Sterane $=0,2)$, а в составе аренов ретен, кадален и перилен присутствуют лишь в следовых количествах (рис. 7), что указывает на доминирующую роль термально зрелого РОВ в составе осадочного материала.

В сероцветных отложениях нижней части разреза содержание биогопанов заметно возрастает $\quad(\mathrm{C} 30 \beta \beta / C 30 \alpha \beta=0,8 \quad \mathrm{C} 30 \beta \alpha /(\alpha \beta+\beta \alpha)=0,33), \quad$ стерены преобладают над геостеранами (Sterene/Sterane=2,5) и представлены олеан-12-ен и фридоолеан-18-ен, диагентическими продуктами трансформации $\beta$-амиринов и тараксолов, типичных компонентов биомассы покрытосеменной наземной флоры [Killops, Frewin 1994; Rontani et al., 2017]. Присутствие олеаненов не характерно для РОВ глубоководных океанских осадков, поскольку молекулярная структура этих соединений термодинамически нестабильна и не способствует их сохранности при дальнем переносе и/или в условиях окислительного диагенеза [Rontani et al., 2017].

В составе полиаренов резко возрастает роль маркеров терригенного ОВ - кадалена, ретена и перилена, при этом их среднее суммарное содержание в осадке заметно выше (72мкг/гСорг), чем в сероцветных отложениях юго-западного склона (43мкг/гСорг).

Можно было бы предположить, что природа и механизм формирования сероцветных осадков западного (АЛР-07-18-сц) и юго-западного (АЛР-07-28-сц) склонов хр. Ломоносова аналогичны. Однако сопоставление биомаркерных показателей (рис. 8) свидетельствует о различиях как в источниках, так и условиях преобразования РОВ. Судя по составу высокомолекулярных н-алканов в исходном ОВ этих отложений преобладали разные таксономические группы наземной биоты: в первом случае высшая древесная растительность (н-С27>н-С31), во втором - травянистая (мхи) (н-С27<н-C31) [Diefendorf, Freimuth, 2017].

Уровень преобразования РОВ осадков западного склона выше, на что указывают значения гопановых и стерановых коэффициентов термальной зрелости и более высокое содержание литифицированных н-алканов.

Соотношение диастеранов и стеранов (St27 dia/reg) даёт основание предполагать, что сероцветные отложения юго-западного склона содержат РОВ, связанное преимущественно с терригенным (глинистым) осадочным материалом [Peters, Moldovan, 10 
2004; Гордадзе, 2015]. Высокое значение гомогопанового индекса для РОВ осадков западного склона может быть показателем бескислородных условий осадконакопления [Peters, Walters, Moldowan, 2005]. Последнее согласуется с реконструкцией биофациальной обстановки, приведённой в работе [Басов и Куприянова, 2010].

Таким образом, учитывая морфоструктурную позицию колонки АЛР-07-18 (приуроченность к крутому склону), вероятность перерыва в осадконакоплении, обусловленного гидродинамическими и/или тектоническими процессами, сероцветные отложения в осадочном разрезе западного склона хр. Ломоносова могли сформироваться в дочетвертичное время. Приуроченность разреза колонки ALR-07-18 к зоне эрозионного несогласия [Рекант и др., 2015] и близкое расположение выхода миоценовых отложений [Stein et al., 2016] позволяет предположить, что формирование сероцветных отложений могло проходить in situ в неритовых условиях в период регрессии. Данное предположение представляется непротиворечивым, поскольку, согласно сейсмогеологической модели строения осадочного чехла хр. Ломоносова [Backmann et al., 2008; Рекант, Гусев, 2012], в миоцене-плиоцене происходит смена мелководных условий осадконакопления глубоководными. Возможно также их формирование в результате размыва и переотложения дочетвертичных (неогеновых?) осадочных отложений.

\section{ВЫВОДЫ}

- Проведены аналитические исследования донных отложений 9 осадочных колонок (113 обр.), отобранных на внешнем шельфе моря Лаптевых, континентальном склоне, его подножии и абиссальном продолжении в котловине Амундсена, а также в зоне сочленения континентального склона с хребтом Ломоносова и в его осевой части. Определены основные органогеохимические параметры, включая состав и распределение углеводородных биомаркеров (алканов, изопреноидов, терпанов, стеранов, аренов), отражающие генезис и уровень термальной зрелости РОВ, что позволяет охарактеризовать источники, пути поступления и условия депонирования осадочного материала.

- Показано, что голоцен-плейстоценовое осадконакопление на внешнем шельфе моря Лаптевых преимущественно определяется поступлением терригенного осадочного материала и контролируется мощным выносом речного стока и Трансполярным дрейфом. В осадочном разрезе зоны континентального склона и его подножия интенсивное влияние терригенного сноса в целом сохраняется. В северо-восточной части котловины Амундсена наряду с потоком терригенного осадочного материала возможен вклад продуктов денудации коренных пород.

- Осадки гребневой части хребта Ломоносова и верхней части разрезов склоновых осадочных колонок содержат РОВ постдиагенетического уровня трансформации, основным источником которого является терригенный материал, главным образом, поставляемый сезонными/паковыми льдами и/или айсбергами.

- Специфика параметров, характеризующих РОВ сероцветных отложений осадочных разрезов юго-западного и западного склонов хр. Ломоносова 
позволяет связать их формирование с периодами депонирования осадочного материала, обогащённого слабо преобразованным гумусовым РОВ. В зоне сочленения континентального склона и южного склона хр. Ломоносова его поступление может быть обусловлено режимом регрессии с выходом палеодельт вплотную к бровке шельфа. Приуроченные к крутому западному склону сероцветные отложения могли формироваться in situ в неритовых условиях в период регрессии. Возможно также их депонирование в результате размыва и переотложения дочетвертичных (неогеновых?) осадочных отложений.

\section{СПИСОК ЛИТЕРАТУРЫ}

Басов В.А., Куприянова Н.В. Стратиграфия и фации осадков по фораминиферам из грунтовых трубок экспедиции «Арктика-2007» (хребет Ломоносова). Геологогеофизические характеристики литосферы Арктического региона. Вып. 7. Тр. ВНИИОкеангеология, 2010,т. 210, с. 71-81.

Гордадзе Г.Н. Углеводороды в нефтяной геохимии. Теория и практика. Москва, РГУНГ им. И.М. Губкина , 2015, 559с.

Гусев Е.А, Сколотнев С.Г., Александрова Г.Н., Былинская М.Е, Головина Л.А., Запорожец Н.И., Лайба А.А., Ляпунов С.М., Радионова Э.П. Первые результаты изучения глубоководных илов с Северного полюса //Доклады РАН, 2008, т. 421, № 6, с. 790-794.

Гусев Е.А., Рекант П.В., Крылов А.А., Басов В.А., Куприянова Н.В., Шкарубо С.И. Кайнозойская история Арктики по результатам геологического опробования. Геология полярных областей Земли. Материалы XLII Тектонического совещания, 2009, т. 1, с. 166169.

Гусев Е.А., Лукашенко Р.В., Попко А.О., Рекант П.В., Миролюбова Е.С., Пяткова М.Н. Новые данные о строении склонов подводных гор поднятия Менделеева (Северный Ледовиный океан // Доклады РАН, 2014, т. 455, № 2, с. 184-188.

Данилов И.Д. Полярный литогенез. Москва, Изд-во Недра, 1978, 238 с.

Зинченко А.Г. Два типа континентальных склонов в Северном Ледовитом океане (в связи с проблемой внешней границы континентального шельфа).70 лет в Арктике, Антарктике и Мировом Океане. Сб. научных трудов под. ред. В.Д. Каминского, СанктПетербург, ВНИИОкеангеология, 2018, с.31-39.

Кабаньков В.Я., Андреева И.А., Иванов В.Н., Петрова В.И., 2004, О геологической природе системы Центрально-Арктических морфоструктур и геологическое значение донных осадков в ее определении // Геотектоника, 2004, № 6, с. 33-48.

Левитан М.А., Лаврушин Ю.А., Штайн Р. Очерки истории седиментации в Северном Ледовитом океане и морях субарктики в течение последних 130 тыс. лет. Москва, ГЕОС, 2007, 404c.

Остроухов С.Б., Цыганкова В.А., Попова П.Ф. Биомаркеры (кадален и ретен) юрско-меловых отложений северного Каспия и возможности их использования при палеогеографических реконструкциях. Осадочные бассейны, седиментационные и постседиментационные процессы в геологической истории. Материалы VII Всероссийского литологического совещания, Новосибирск, 2013, т. 2, с. 356-359.

Петрова В.И., Батова Г.И., Куршева А.В., Литвиненко И.В. Геохимия органического вещества донных отложений провинции центрально-арктических поднятий Северного Ледовитого океана // Геология и геофизика, 2010, т. 51, №1 , с. 113-125.

Рекант П.В., Гусев Е.А., Виноградов В.А. Морфология фундамента и структура осадочного чехла южной части хребта Ломоносова |// Геология полярных областей Земли. МатериалыXLII Тектонического совещания, 2009, т. 2, с. 146-148. 
Рекант П.В., Гусев Е.А. Сейсмогеологическая модель строения осадочного чехла прилаптевоморской части хр. Ломоносова и прилегающих частей глубоководных котловин Амундсена и Подводников //Геология и геофизика, 2012, т. 53, № 11, с. 1497-1512.

Рекант П.В., Миролюбова Е.С., Андреева И.А., Смирнова Л.С. Сравнительный анализ минералогических ассоциаций донных отложений прилаптевоморского сегмента хр. Ломоносова и поднятия Менделеева как один из критериев оценки источников обломочного материала // Проблемы Арктики и Антарктики, 2013, № 4 (98), с.79-95.

Рекант П.В. Петров О.В., Кашубин С.Н., Рыбалка А.В., Винокуров И.Ю., Гусев Е.А. История формирования осадочного чехла глубоководной части арктического бассейна по данным сейсмических исследований МОВ-ОГТ //Региональная геология и металлогения, 2015, т. 64, с. 11-27.

Рекант П.В., Кабаньков В.Я., Андреева И.А., Петров О.В., Беляцкий Б.В., Соболев Н.Н. Геологическое опробование коренных пород хребта Ломоносова как ключ к пониманию его геологической природы //Региональная геология и металлогения, 2018, № 75, c. 5-22.

Романкевич Е.А. Геохимия органического вещества в океане. Москва, Изд-во Наука, 1977, 256 с.

Романкевич Е.А., Ветров А.А. Цикл углерода в арктических морях России. Москва, Изд-во Наука, 2001, 302 с.

Система моря Лаптевых и прилегающих морей: современное состояние и история развития. Под ред. Х. Кассенс, А.П. Лисицина, Й. Тиде и др. Москва, МГУ, 2009, 608с.

Талденкова Е.Е., Николаев С.Д., Рекант П.В., Погодина И.А., Портнов А.Д. Палеогеография хребта Ломоносова (Северный Ледовитый океан) в плейстоцене: литология осадков и микрофауна //Вестник МГУ, серия. 5. геогр., 2009, № 4, с. 45-54.

Backman J., Jakobsson M., Frank M.; Sangiorgi F.; Brinkhuis H.; Stickley C.; O'Regan M; Løvlie R; Pälike H; Spofforth D; Gattacceca J; Moran K; King J; Heil C. Age model and core-seismic integration for the Cenozoic Arctic Coring Expedition sediments from the Lomonosov Ridge. 2008, Paleoceanography, 23(1), PA1S03, https://doi.org/10.1029/2007PA001476/

Bastow, T.P., Singh, R.K., van Aarssen, B.G.K., Alexander, R., Kagi, R.I. 2-Methylretene in sedimentary material: a new higher plant biomarker //Organic Geochemistry , 2001, v. 32, p.12111217.

Belicka, L.L., MacDonald, R.W., Harvey, H.R., 2002. Sources andtransport of organic carbon to shelf, slope, and basin surface sediments of the Arctic Ocean. Deep-Sea Research. Part 1. Oceanographic Research Papers, 2002, v.49 (8), p.1463-1483.

Brassell S., Eglinton G., Howell V. Paleoenvironmental assessment of marine organicrich sediments using molecular organic geochemistry. From: Brooks J, Fleet A. Marine Petroleum Source Rocks. Geological Society, Special Publication, 1987, N 26, p. 79-98.

Connon J., Cassou A.M. Properties of gases and petroleum lipids derived from terrestrial kerogen at various maturation levels // Geochimica et Cosmochimica Acta, 1980, N 44, p. 1-23.

Diefendorf A., Freimuth E. Extracting the most from terrestrial plant-derived n-alkyl lipids and their carbon isotopes from the sedimentary record. A review Organic Geochemistry, 2017, v.103, p. 1-21.

Eglinton G., Murphy M.T.J. Organic Geochemistry: method and results. Berlin, Springer, 1969, 828 p.

Grantz A., Pease V.L., Willard D.A. Phillips K. L., Clark D. L. . Bedrock cores from 89 North: Implications for the geologic framework and neogene paleoceanography of Lomonosov ridge and a tie to the Barents shelf // Bull. Geol. Soc. Am., 2001, v.l., 1130, N 10, p. 1272-1281.

Greenwood P.F., Leenheer J.A., McIntyre C., Berwick L., Franzmann P.D. Bacterial biomarkers thermally released from dissolved organic matter //Organic geochemistry, v. 37, I. 5, 2006, p. 597-609. 
Hautevelle Y., Michels R., Malartre F., Trouiller A. Vascular plant biomarkers as proxies for paleoflora and paleoclimatic changes at the Dogger/Malm transition of the Paris Basin (France) // Organic Geochemistry, 2006, v.37, p. 610-625.

Innes H.E., Bishop A.N., Fox P.A., Head I.M. and Farrimond P. Early diagenesis of bacteriohopanoids in Recent sediments of Lake Pollen, Norway //Organic Geochemistry, 1998, p.1285-1295.

Jakobsson M., Lovlie R., Arnold E., Backman J., Polyak L., Knutsen J.O., Musatov E., Pleistocene stratigraphy and paleoenvironmental variation from Lomonosov Ridge sediments,central Arctic Ocean //Global Planet Change, 2001, v.31, p.1-21.

Kassens H., Bauch H. A., Dmitrienko I..A., Eicken H., Hubberten H.-W., Melles M., Thide J., Timokhov L.A. (Eds.) Land-Oceane System in the Siberian Arctic: dynamics and history, 1999, Springer, Berlin, Heidelberg, New-York, 711 p.

Killops S.D., Frewin N.L. Triterpenoid diagenesis and cuticular preservation // Organic Geochemistry, 1994, v. 21, I. 12, p. 1193-1209.

van Koeverden J. H.,. Karlsen D. A and Backer-Owe K. Carboniferous non-marine source rocks from Spitsbergen and Bjornjya: comparison with the western Arctic // Journal of Petroleum Geology, 2011, v. 34(1), p. 53 - 66.

Nytoft H.P., Bojesen-Koefoed J. A. $17 \alpha, 21 \alpha(\mathrm{H})$-hopanes: natural and synthetic //Organic Geochemistry, 2001, p.841-856.

Peters K., Walters C., Moldowan J. The biomarker guide. Cambridge University Press, 2004, 364 p.

Polyak L., Curry W., Darby D., Bischof J., Cronin T. Contrasting glacial/interglacial regimes in the western Arctic Ocean as exemplified by a sedimentary record from the Mendeleev Ridge //Palaeogeography, Palaeoclimatology, Palaeoecology, 2004, v. 203, p. 73-93.

Rontani J-F., Amiraux R., Artigue L., Belt S. T. Identification of di- and triterpenoid lipid tracers confirms the significant role of autoxidation in the degradation of terrestrial vascular plant material in the Canadian Arctic //Organic Geochemistry, 2017, v. 108, p. 43-50.

Shanmugam G., Moiola R. J. Sedimentary facies of the Nova Scotian upper and middle continental slope, offshore eastern Canada //Sedimentology, 1985, v. 32, I.3, p. 455-455.

Stein R., Boucsein B., Fahl K., Garcia de Oteyza T., Knies J., Niessen F. Accumulation of particulate organic carbon at the Eurasian continental margin during late Quaternary times: controlling mechanisms and paleoenvironmental significance //Global Planet Change, 2001, v.31, p. 87-102.

Stein, R., Fahl K., Schreck M., Knorr G., Niessen F., Forwick M., Gebhardt C., Jensen L., Kaminski M., Kopf A., Matthiessen J., Jokat W., Lohmann G. 2016. Evidence for ice-free summers in the late Miocene central Arctic Ocean //Nature Communications, 2016, v. 7, p. 1-13.

Suzuki N., Yessalina S., Kikuchi T. Probable fungal origin of perylene in Late Cretaceous to Paleogene terrestrial sedimentary rocks of northeastern Japan as indicated from stable carbon isotopes //Organic Geochemistry, 2010, v. 41, p. 234-241.

Tessi T., Semiletov I., Dudarev O., Andersson A., Gustafsson O. Matrix association effects on hydrodynamic sorting and degradation of terrestrial organic matter during cross-shelf transport in the Laptev and East Siberian shelf seas //Geophys. Res. Biogeosci., 2016, v.121, p.731-752.

The organic carbon cycle in the Arctic ocean Ed.: Stein R., Macdonald R. SpringerVerlag, 2004, 363 p.

van Koevrden J. H. and Karlsen, D. A. Carboniferous non-marine source rocks from Svalbard and Bjørnøya: comparison with the Western Arctic //Journal of Petroleum Geology, 2011, v. 34, p. 53-66. 
Venkatesan M., Ruth E., Steinberg S., Kaplan I. Organic geochemistry of sediments from the continental margin off southern New England, USA Venkatesan M. Occurrence and possible sources of perylene in marine sediments //Marine Chemistry, 1987, v. 25, N 1, p. 1-27.

Yamamoto M., Okino T., Sugisaki S., Sakamoto T. Late Pleistocene changes in terrestrial biomarkers in sediments from the central Arctic Ocean //Organic geochemistry, 2008, v.39 p.754-763.

Yamamoto M., Polyak L. Changes in terrestrial organic matter input to the Mendeleev Ridge, Arctic Ocean during the Late Quaternary //Global and Planetary Change, 2009, v. 68, p. 30-37.

Yunker M. B., Robie W., Macdonald R.W., Snowdon L. R,. Fowler B. R. Alkane and $\mathrm{PAH}$ biomarkers as tracers of terrigenous organic carbon in Arctic Ocean sediments //Organic Geochemistry, 2011, v.42, p.1109-1146. 
Подписи к рисункам статьи: Молекулярная геохимия рассеянного органического вещества позднекайнозойских отложений лаптевоморской континентальной окраины и прилегающей части СЛО.

В.И. Петрова, Г.И. Батова, А.В. Куршева, И.В. Литвиненко, И.П. Моргунова

Рисунок 1.Карта района исследований

Рисунок 2. Литолого-геохимическая характеристика изученных осадочных колонок

Рисунок 3. Характеристика н-алканов и изопреноидов

Рисунок 4. Фациально-генетическая характеристика РОВ по стеранам

Рисунок 5. Характеристика термальной зрелости РОВ по терпанам Рисунок 7. Рисунок 6. Корреляция осадочных колонок юго-западного склона хребта Ломоносова

Рисунок 7. Корреляция осадочных колонок западного склона хребта Ломоносова

Рисунок 8. Сравнительная характеристика молекулярного состава РОВ сероцветных отложений юго-западного и западного склонов хр. Ломоносова. 
Статья: Молекулярная геохимия рассеянного органического вещества позднекайнозойских отложений лаптевоморской континентальной окраины и прилегающей части СЛО.

В.И. Петрова, Г.И. Батова, А.В. Куршева, И.В. Литвиненко, И.П. Моргунова

Таблица 1. Геохимическая характеристика РОВ (осреднённые данные)

\begin{tabular}{|c|c|c|c|c|c|c|c|c|c|c|c|c|c|}
\hline \multirow{2}{*}{$\begin{array}{l}\text { № } \\
\text { Станции }\end{array}$} & \multicolumn{2}{|c|}{ Координаты } & \multirow{2}{*}{$\begin{array}{c}\text { Глубина } \\
\text { моря, м }\end{array}$} & \multicolumn{6}{|c|}{ Содержание в осадке,\% } & \multicolumn{4}{|c|}{ Групповой состав ОВ,\% } \\
\hline & C.II. & в.д. & & Скарб & Сорг & OB & Ахл & Асп-б & $\overline{\Gamma K}$ & $\overline{\text { Ахл }}$ & Асп-б & $\Gamma \bar{\Gamma}$ & $\overline{\mathrm{OOB}}$ \\
\hline AФ-07-26 & 75 49. 51 & 13444.32 & 43 & 0,05 & 1,18 & 2,14 & 0,023 & 0,039 & 0,33 & 1,1 & 1,8 & 15,5 & 81,6 \\
\hline AФ-05-29 & 7737.60 & 13817.73 & 45 & 0,02 & 1,02 & 1,85 & 0,029 & 0,024 & 0,22 & 1,6 & 1,3 & 12,0 & 85,1 \\
\hline АФ-31 & 7837.66 & 13733.90 & 620 & 0,02 & 0,76 & 1,41 & 0,018 & 0,02 & 0,19 & 1,27 & 1,16 & 13,07 & 84,5 \\
\hline AФ-33 & 8150.26 & 13708.61 & 3500 & 0,08 & 0,51 & 0,93 & 0,01 & 0,01 & 0,03 & 1,34 & 1,10 & 1,63 & 95,9 \\
\hline АФ-34 & 8957.97 & 5909.72 & 4270 & 0,15 & 0,37 & 0,68 & 0,01 & 0,01 & 0,00 & 2,20 & 1,27 & 0,00 & 96,5 \\
\hline АЛР-28 & $80 \quad 44.12$ & 14018.23 & 1414 & 0,03 & 0,22 & 0,41 & 0,004 & 0,004 & 0,01 & 1,0 & 1,1 & 0,2 & 97,6 \\
\hline АЛР-28сц & & & & 0,14 & 0,59 & 1,06 & 0,014 & 0,009 & 0,16 & 1,4 & 0,8 & 15,6 & 82,2 \\
\hline АЛР-22 & 8142.04 & 14258.29 & 965 & 0,05 & 0,25 & 0,46 & 0,004 & 0,005 & 0,00 & 0,91 & 1,1 & 0,0 & 98,0 \\
\hline АЛР-17 & $82 \quad 30.49$ & 14211.03 & 1100 & 0,05 & 0,18 & 0,33 & 0,003 & 0,004 & 0,00 & 1,1 & 1,3 & 0,0 & 97,5 \\
\hline АЛР-18 & $82 \quad 32.39$ & 14142.23 & 1500 & 0,04 & 0,21 & 0,39 & 0,004 & 0,007 & 0,02 & 1,4 & 2,2 & 1,6 & 94,9 \\
\hline АЛР-18сц & & & & 0,03 & 0,54 & 0,98 & 0,007 & 0,015 & 0,17 & 0,7 & 1,5 & 16,8 & 81,1 \\
\hline
\end{tabular}


Статья: Молекулярная геохимия рассеянного органического вещества позднекайнозойских отложений лаптевоморской континентальной окраины и прилегающей части СЛО.

\section{В.И. Петрова, Г.И. Батова, А.В. Куршева, И.В. Литвиненко, И.П. Моргунова}

Таблица 2. Геохимическая характеристика битумоидов (осреднённые данные)

\begin{tabular}{|c|c|c|c|c|c|c|c|c|}
\hline \multirow{2}{*}{$\begin{array}{l}\text { № } \\
\text { Станции }\end{array}$} & \multicolumn{3}{|c|}{ Состав Ахл,\% } & \multicolumn{2}{|c|}{$\%$ УВ } & \multicolumn{2}{|c|}{$\begin{array}{l}\text { Состав УВ, } \\
\%\end{array}$} & \multirow[t]{2}{*}{ Me-Nf / Ar } \\
\hline & масла & смолы & асф-ны & в осадке & B OB & Me-Nf & Ar & \\
\hline АФ-07-26 & 14,3 & 84,0 & 1,8 & 0,003 & 0,2 & 82,7 & 16,7 & 5,2 \\
\hline АФ-05-29 & 28,9 & 66,8 & 4,3 & 0,009 & 0,5 & 87,4 & 12,6 & 8,3 \\
\hline АФ-31 & 22,4 & 76,3 & 2,5 & 0,004 & 0,3 & 83,4 & 16,6 & 6,4 \\
\hline АФ-33 & 32,5 & 62,4 & 5,1 & 0,004 & 0,4 & 85,7 & 14,3 & 7,4 \\
\hline АФ-34 & 43,8 & 52,1 & 4,1 & 0,006 & 1,0 & 87,8 & 12,2 & 9,3 \\
\hline АЛР-28 & 39,8 & 55,7 & 4,5 & 0,002 & 0,4 & 83,1 & 16,9 & 4,9 \\
\hline АЛР-28сц & 24,1 & 73,6 & 2,4 & 0,004 & 0,3 & 85,1 & 14,9 & 5,7 \\
\hline АЛР-22 & 29,4 & 64,8 & 5,9 & 0,001 & 0,3 & 85,4 & 14,6 & 6,5 \\
\hline АЛР-17 & 38,6 & 56,9 & 4,5 & 0,001 & 0,5 & 86,0 & 14,0 & 6,5 \\
\hline АЛР-18 & 36,1 & 62,1 & 1,8 & 0,002 & 0,5 & 80,1 & 19,9 & 4,0 \\
\hline АЛР-18сц & 16,6 & 81,5 & 2,0 & 0,001 & 0,1 & 75,0 & 25,0 & 3,0 \\
\hline
\end{tabular}


Статья: Молекулярная геохимия рассеянного органического вещества позднекайнозойских отложений лаптевоморской континентальной окраины и прилегающей части СЛО.

В.И. Петрова, Г.И. Батова, А.В. Куршева, И.В. Литвиненко, И.П. Моргунова

Таблица 3. Характеристика н-алканов и изопреноидов (осреднённые данные)

\begin{tabular}{|c|c|c|c|c|c|c|c|}
\hline Станция & $\begin{array}{c}\text { CPI } \\
22-30 \\
\end{array}$ & $\mathbf{P r} / \mathbf{P h}$ & Kiso & TAR & OEP17-19 & OEP27-31 & $\begin{array}{l}\text { Litpic n-Alk } \\
\text { mkg/gCorg }\end{array}$ \\
\hline АФ-07-26 & 2,75 & 1,01 & 0,35 & 14,83 & 1,26 & 4,20 & 0,95 \\
\hline АФ-05-29 & 2,62 & 0,92 & 0,74 & 4,22 & 1,05 & 4,23 & 1,66 \\
\hline АФ-05-31 & 2,56 & 0,86 & 0,48 & 6,16 & 0,72 & 4,34 & 5,23 \\
\hline АФ-05-33 & 2,92 & 0,87 & 0,55 & 2,61 & 1,10 & 5,61 & 4,25 \\
\hline АФ-05-34 & 2,53 & 0,84 & 0,61 & 2,00 & 0,87 & 4,72 & 6,20 \\
\hline АЛР-07-28 & 2,90 & 1,26 & 0,88 & 2,34 & 1,08 & 5,52 & 2,22 \\
\hline АЛР-07-28сц & 2,98 & 0,97 & 0,86 & 6,55 & 0,98 & 4,65 & 3,19 \\
\hline АЛР-07-22 & 2,48 & 0,86 & 0,43 & 4,37 & 1,04 & 4,22 & 2,12 \\
\hline АЛР-07-17 & 2,48 & 1,04 & 0,57 & 2,26 & 1,05 & 3,92 & 1,91 \\
\hline АЛР-07-18 & 2,50 & 0,95 & 0,91 & 2,83 & 1,14 & 4,76 & 5,54 \\
\hline АЛР-07-18сц & 2,38 & 1,18 & 0,64 & 5,39 & 1,08 & 3,35 & 4,99 \\
\hline
\end{tabular}

$\mathrm{CPI}_{22-30}=2 *(\mathrm{C} 23+\mathrm{C} 25+\mathrm{C} 27+\mathrm{C} 29) /[(\mathrm{C} 22+2 *(\mathrm{C} 24+\mathrm{C} 26+\mathrm{C} 28)+\mathrm{C} 30]$

Pr/Phy — отношение пристана к фитану.

Kiso $=(\operatorname{Pr}+\operatorname{Phy}) /(n C 17+\mathrm{nC} 18)$.

TAR - (terrigenous to aquatic ratio $)=(\mathrm{C} 27+\mathrm{C} 29+\mathrm{C} 31) /(\mathrm{C} 15+\mathrm{C} 17+\mathrm{C} 19)$

OEP $=\left(C_{n-2}+6 C_{n}+C_{n+2}\right) /\left(4 * C_{n-1}+4 * C_{n-1}\right)$ 


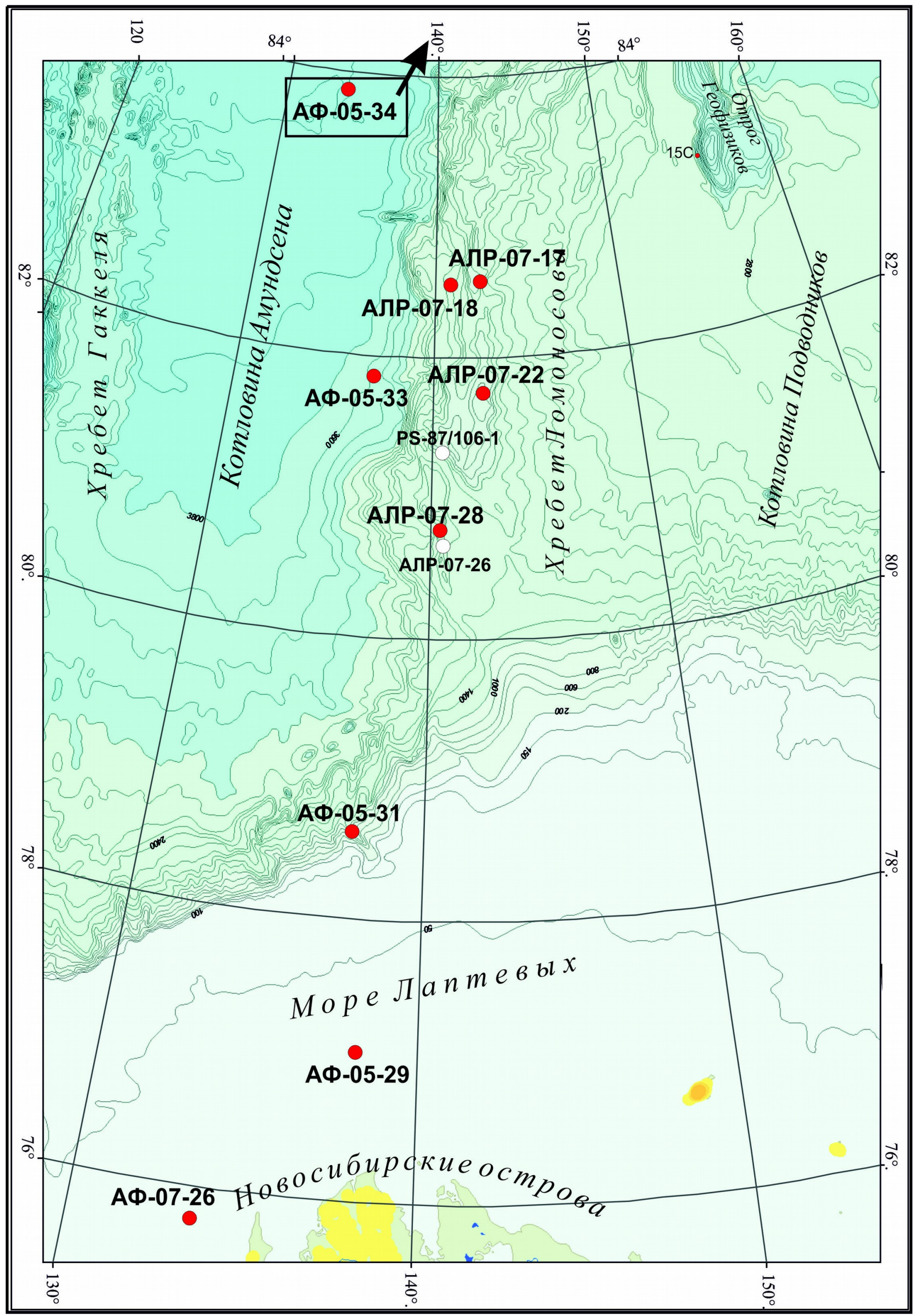



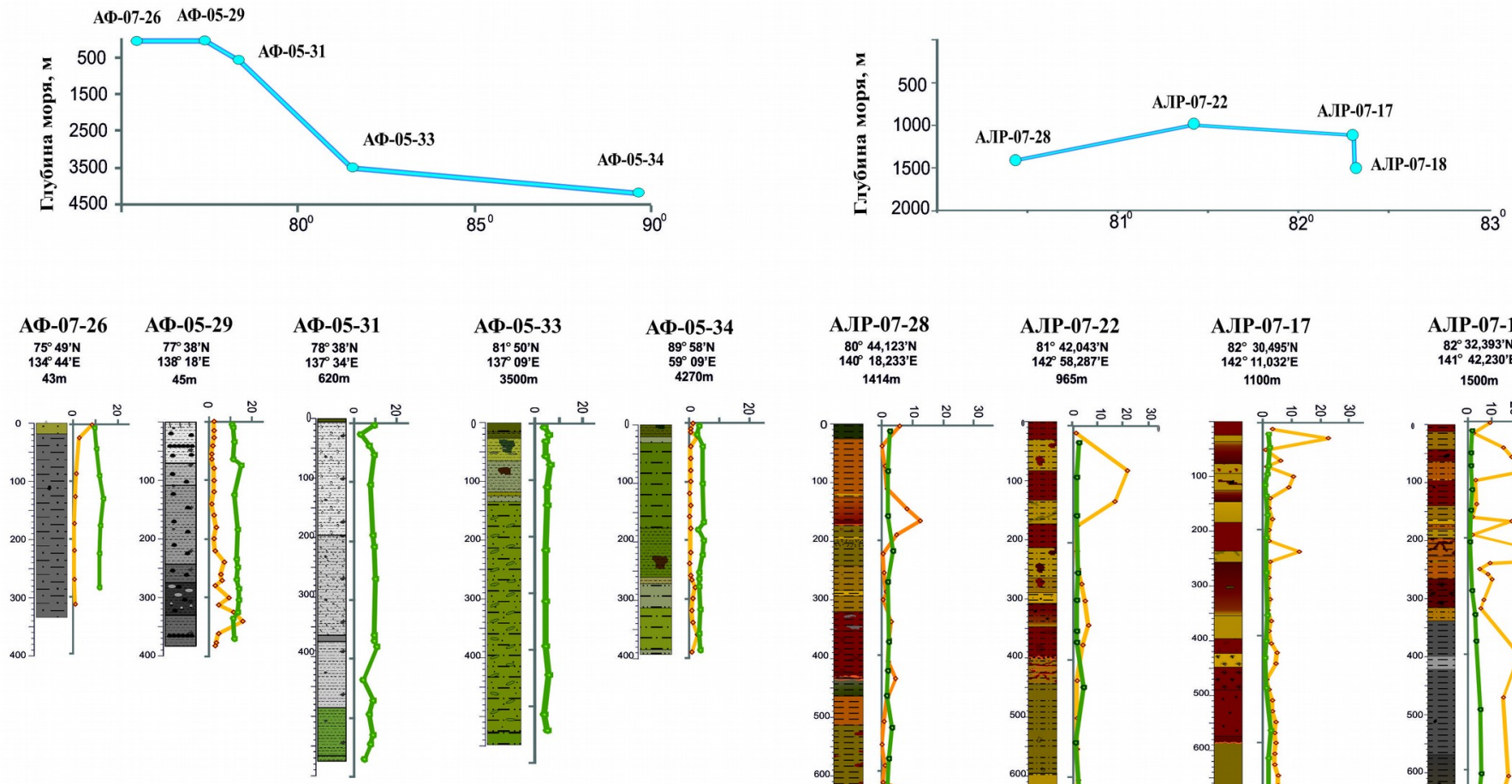

Содержание в осадке, \%

$\diamond$ грубозернистая фракция (>0,63мм)

- Сорг $^{* 10}$

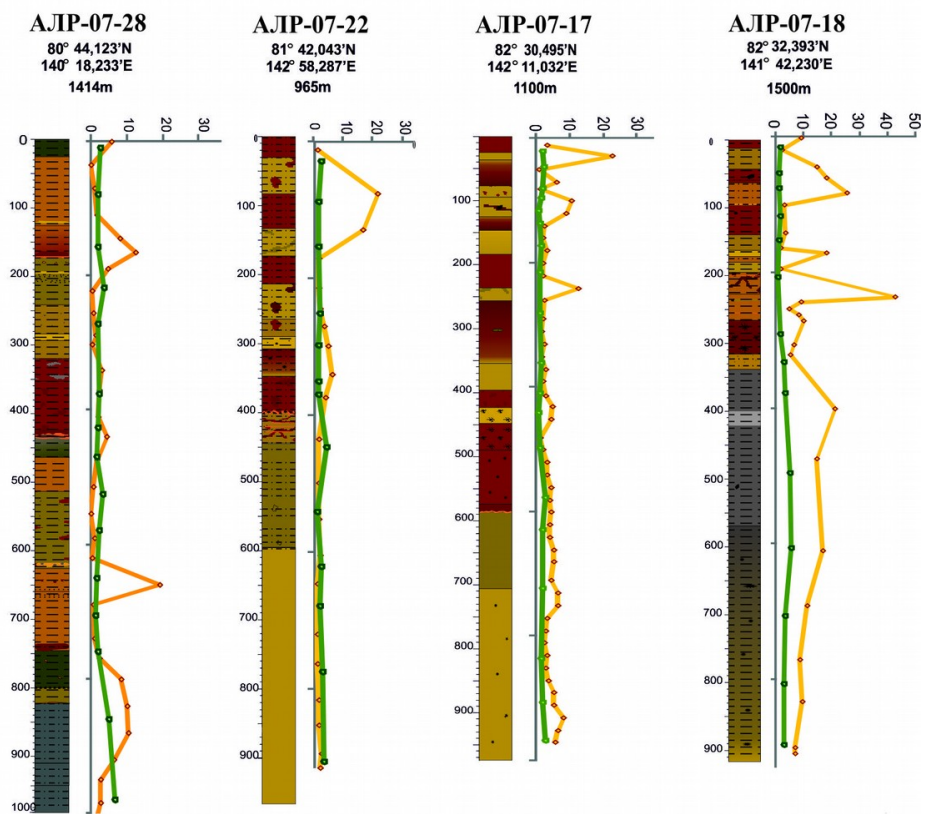




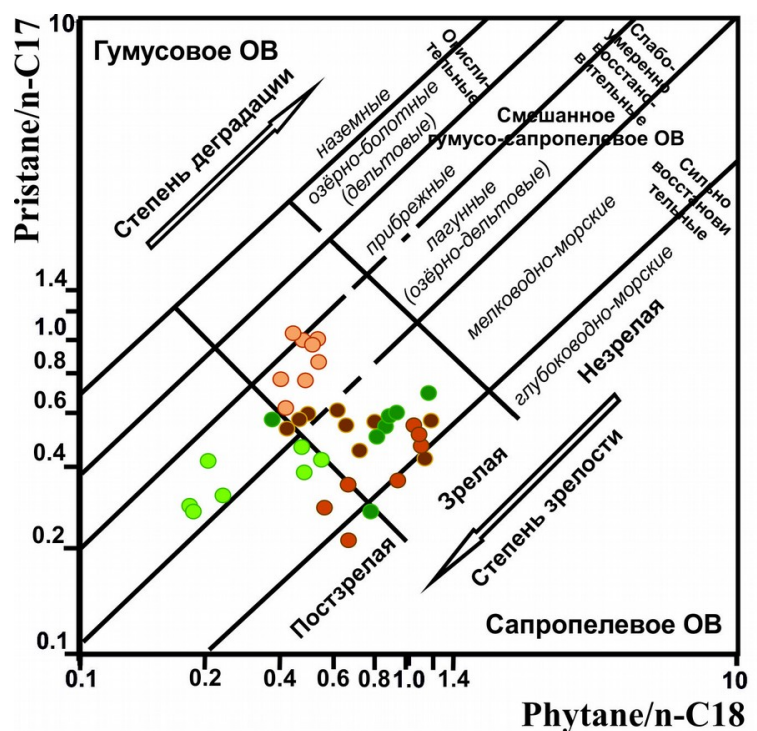

Phytane/n-C18

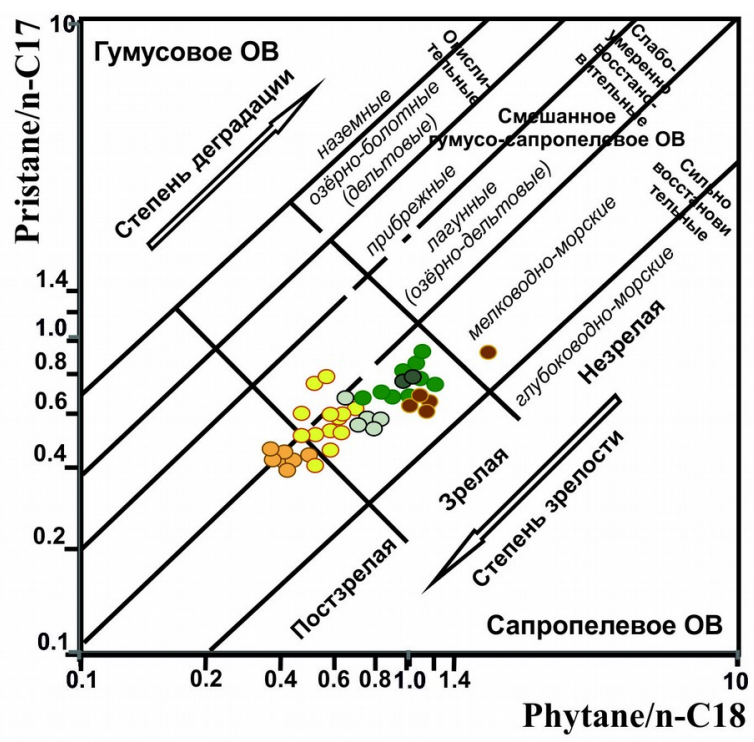

- АЛР-07-28

- АЛР-07-22

○ АЛР-07-17

- АЛР-07-18

- АЛР-07-28сц

О АЛР-07-18сц 


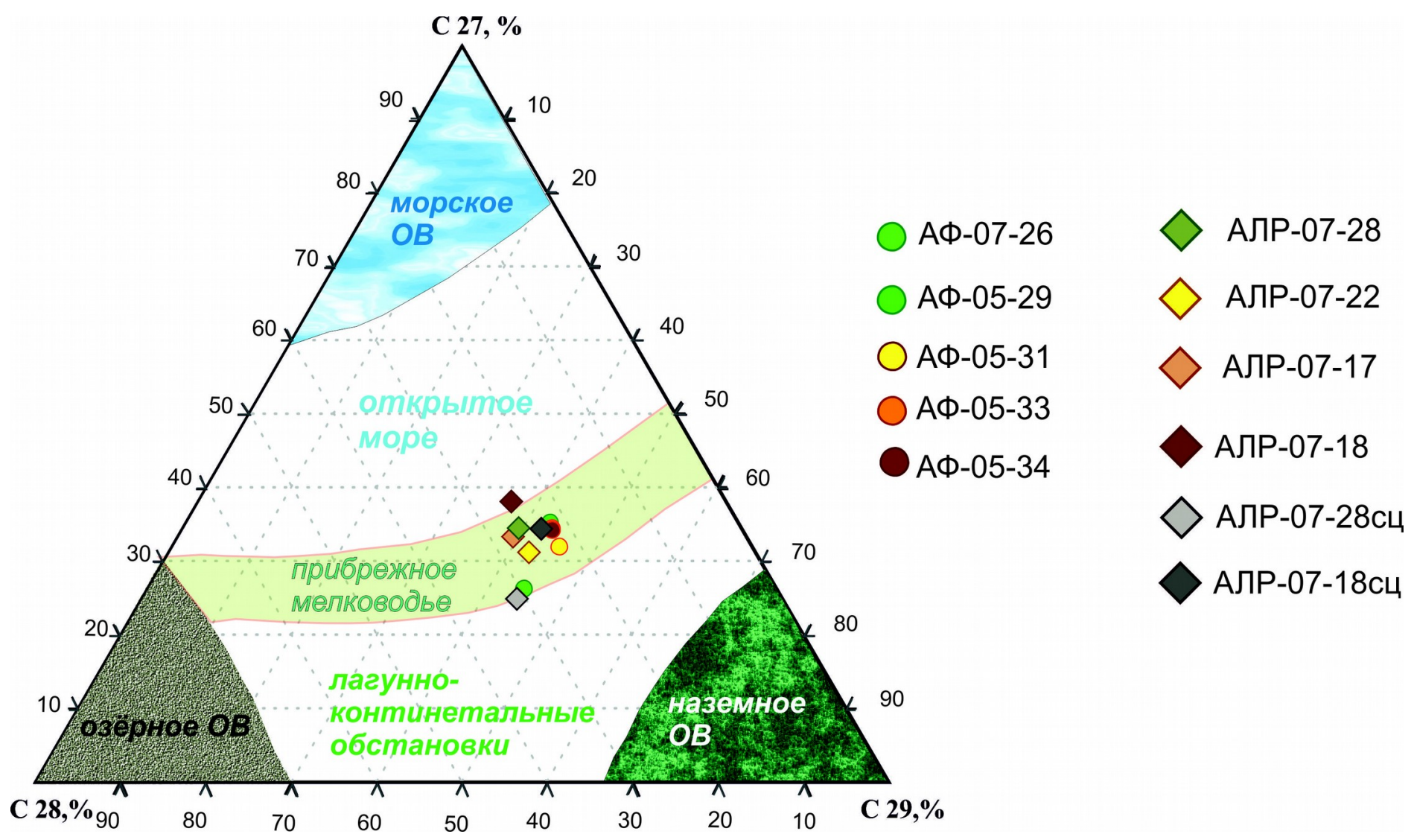




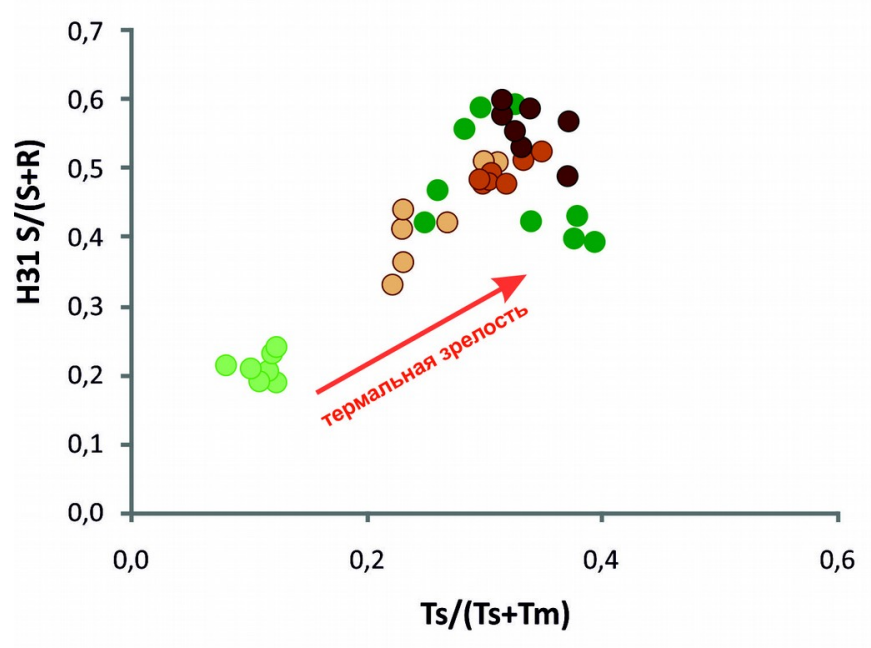

- AФ-07-26

- AФ-05-29

- АФ-05-31

- АФ-05-33

- AФ-05-34

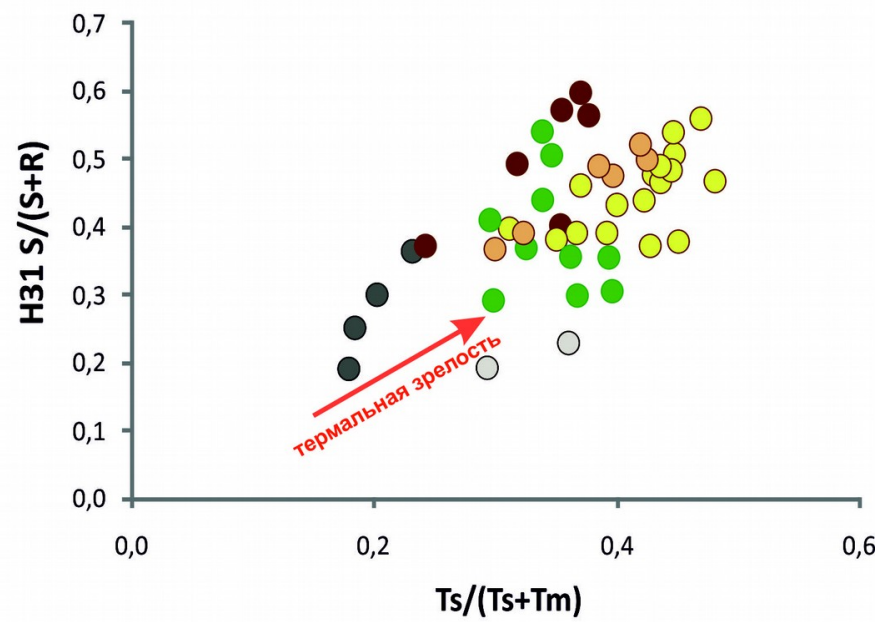

- АЛР-07-28

○ АЛР-07-22

О АЛР-07-17

- АЛР-07-18

О АЛР-07-28сц

- АЛР-07-18Сц 


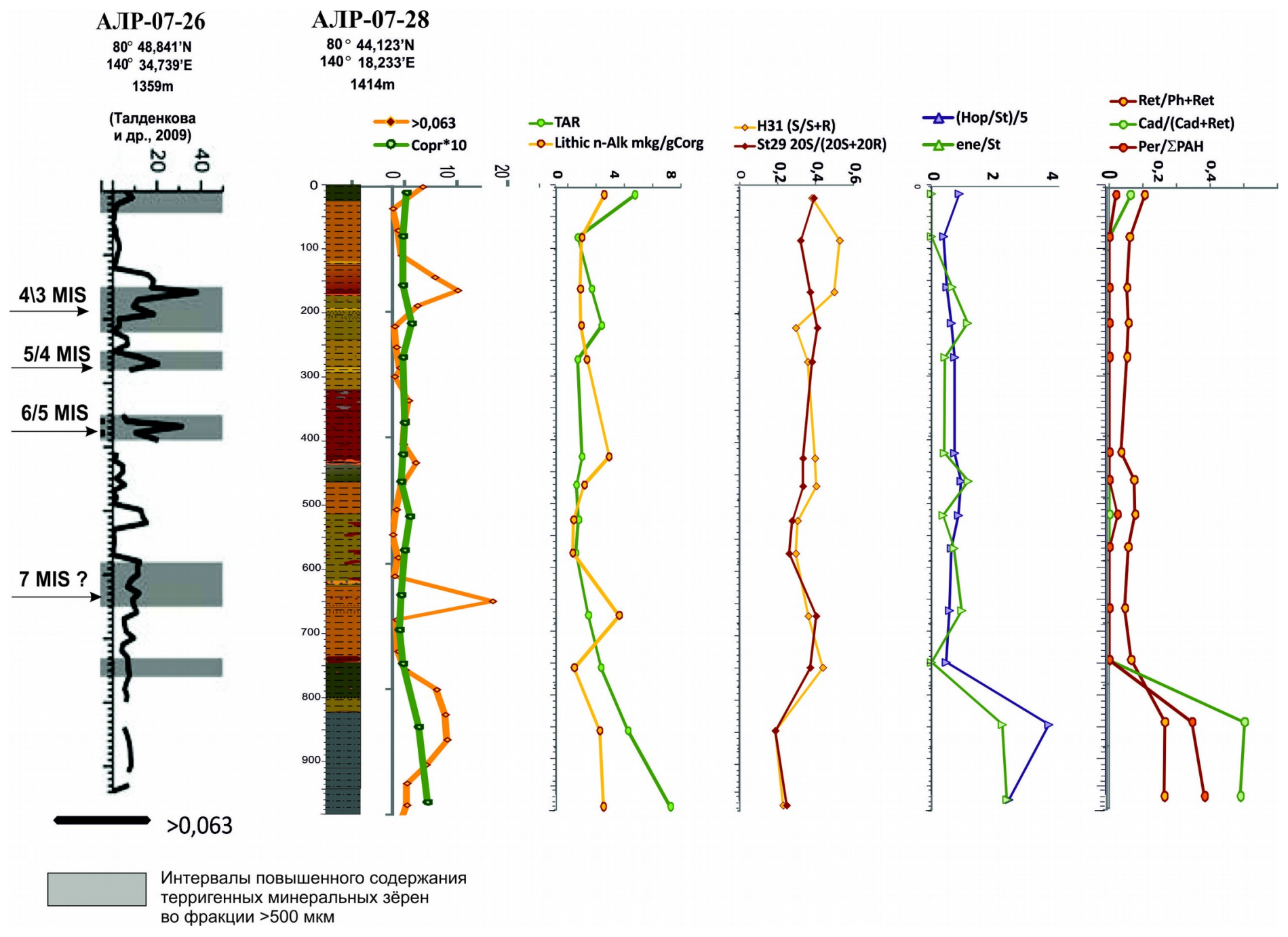




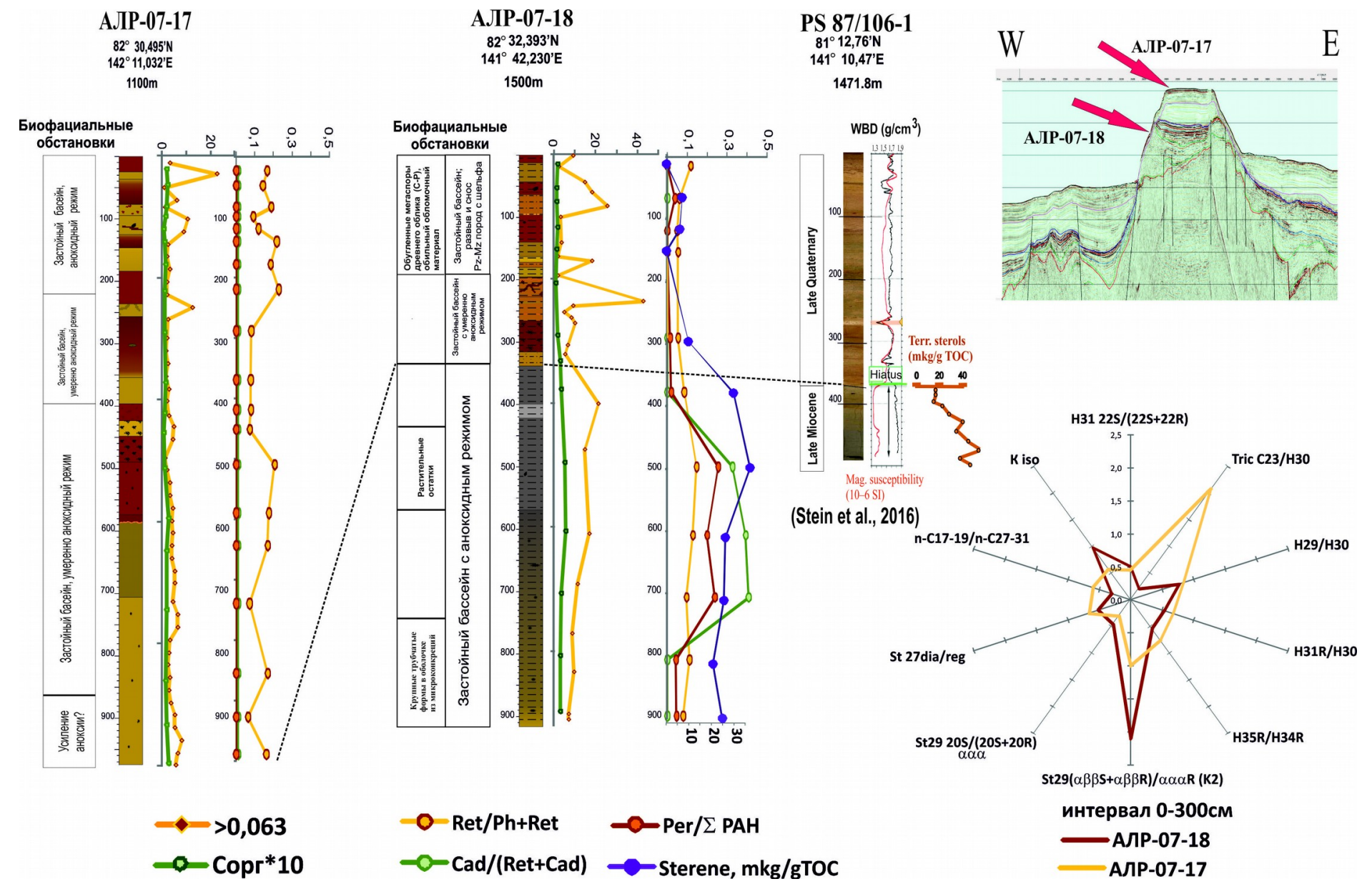




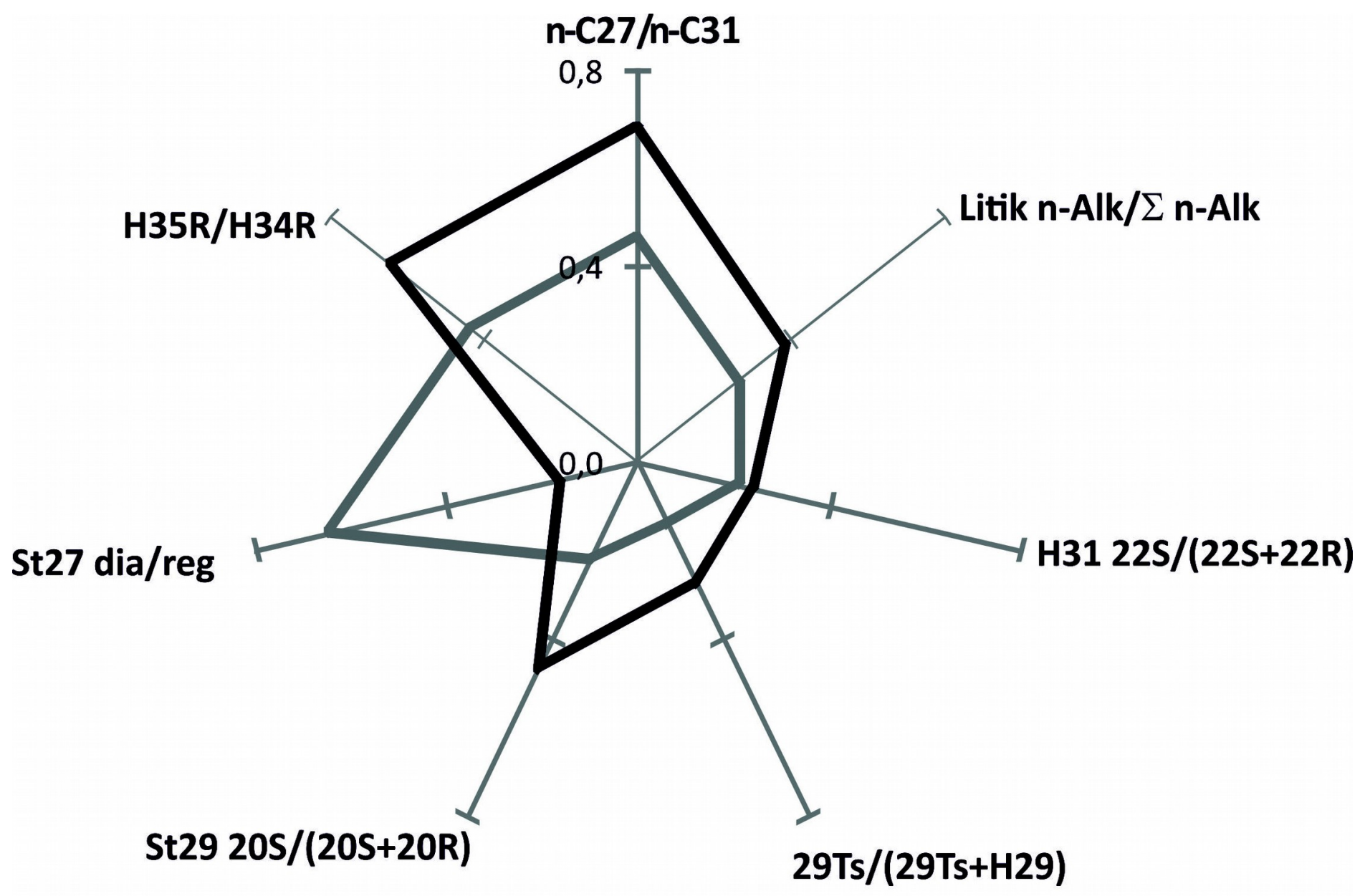

АЛР-07-28сц

—АЛР-07-18сц 